\title{
MANAJEMEN PENGEMBANGAN KECERDASAN MAJEMUK MELALUI METODE PEMBERLAJARAN QUANTUM \\ PADA ANAK USIA DINI
}

\author{
Ach Syaikhu \\ Dosen Tetap IAI Al Falah As Sunniyyah Kencong Jember
}

\begin{abstract}
Management in developing potential (plural intelligence) Early Childhood (AUD) is very important to do. Called Early Childhood, namely children aged 0-6 years. At an early age is a golden age (Golden Age) where during this period the child's process will experience development in itself, both physical, intellectual, social emotional and language. An understanding of the importance of early childhood has an impact on current government policies. One of these policies is the Republic of Indonesia Law Number 20 of 2003 concerning the National Education system. Basically, almost every early childhood education institution has applied quantum learning methods, a teaching method where each teacher will enter the world of students so that students feel comfortable and are not faced with the risk of failure in the learning process.
\end{abstract}

Keyword: Management, Compound Intelligence, Quantum Learning, Early Childhood.

\section{PENDAHULUAN}

Manusia diciptakan Allah agar mereka menjadi kholifah di muka bumi, sehingga mereka telah banyak dibekali dengan apa saja yang telah dibutuhkan untuk kepentingan kekhalifahan itu. Jelas bahwa Allah telah memberi mereka ilmu sebagai kepentingan utama untuk semua itu, sebagaimana bekal yang mula-mula Allah berikan kepada Nabi Adam a.s., yaitu ilmu.

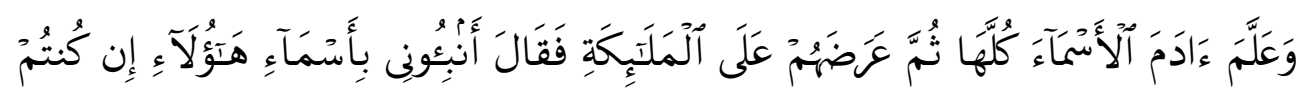<smiles></smiles>

Artinya:

"Allah telah mengajarkan Adam tentang nama-nama (karakteristik) semua yang ada"(Al - Baqoroh: 31) ${ }^{1}$

Disadari atau tidak pendidikan adalah modal utama suatu bangsa (ummat) jika bangsatersebut ingin tetap survive dan bisa bersaing dengan bangsa lain.

1. Departemen Agama RI. 1984. Al-Qur’an dan Terjemah. Semarang.

FALASIFA, Vol. 9 Nomor 2 September 2018 | 35 
Ach Syaikhu

Karena melaluipendidikanlah suatu bangsa dapat menghasilkan individu-individu yang mampu membawa perubahan yang lebih baik (education for better life). Kemudian untuk membentuk individu yang sempurna yang tidak hanya memiliki kemampuan intelegensi tinggi, namun juga harus memiliki kemampuan spiritual yang memadai. Hal ini perlu sedini mungkin ditanamkan pada generasi bangsa, tentunya minal mabdi ila llabdhi.

Nampak sudah Sebagaimana dalam tuntunan syariat Islam bahwa proses pendidikan dimulai sejak dini, yakni diri alam kandungan hingga liang lahat. Sungguh Rosulullah telah mengisyaratkan hal ini jauh sebelum berkembangnya teori-teori pendidikan barat.

Melihat dari kaidah pendidikan Islam, tampaknya penting sekali bahwa pendidikan perlu mendapat perhatian khusus di masa awal seorang anak sebelum dan sesudah lahir. Ketika dalam kandungan tidak terlepas pula bagaimana kaidah tentang pendidikan yang diajarkan Rosulullah terkait pendidikan spiritual-tauhid, emosional-akhlak, maupun nutris yang baik dan halal yang berperan untuk membangun pertumbuhan dan perkembangan fisik anak. Tentunya hal ini tidak terlepas peran utama ibu sebagai pengelola pendidikan anak.

Ketika anak sudah lahir, dimensi pendidikan yang akan dihadapinya begitu kompleks. Hadirnya dunia sebagai lingkungan kedua bagi anak ini mengharuskan si anak untuk beradaptasi dan belajar dengan modal potensi yang dibawanya. Saat itulah si anak butuh bimbingan yang intensif dan terukur.

Seiring dengan pertumbuhan anak dan tanggungjawab serta kesibukan sang ibu, sepertinya tidak cukup pendidikan sebatas lingkungan informal keluarga. Namun, butuh ruang dan waktu khusus agar anak mendapatkan pengalaman belajar lebih guna mengembangkan potensinya, yaitu lembaga pendidikan. Disitulah mucul orang tua kedua yaitu guru atau pendidik terlatih. Untuk menghasilkan buah pendidikan yang membanggakan, dibutuhkan satu manajemen yang benar dan tepat. Berikut para pengelola yang profesional.

Manajemen dalam pengembangan potensi Anak Usia Dini (AUD) adalah hal yang penting dilakukan. Disebut Anak Usia Dini yaitu anak yang berumur 06 tahun. Usia tersebut merupakan usia keemasan (Golden Age) dimana dalam masa tersebut proses anak akan mengalami perkembangan pada dirinya baik itu fisik, intelektual, sosial emosional maupun bahasa. Pemahaman tentang pentingnya masa usia dini, berdampak pada kebijakan pemerintah saat ini. Salah satu kebijakant ersebut dengan UU RI Nomor 20 tahun 2003 tentang sistem Pendidikan Nasional yang isinya sebagai berikut: Pendidikan adalah usaha sadar dan terencana untuk mewujudkan suasana belajar dan proses pembelajaran agar peserta didik secara aktif mengembangkan potensi dirinya untuk memiliki 
kekuatan spritiual keagamaan, pengendalian diri, kepribadian, kecerdasan, akhlak mulia serta ketrampilan yang diperlukan dirinya, masyarakat, bangsa dan negara. Secara khusus PAUD bertujuan untuk membantu pertumbuhan dan perkembangan jasmani dan rohani agar anak memiliki kesiapan untuk memasuki pendidikan yang lebih lanjut. Berkaitan dengan manajemen pada Anak Usia Dini (AUD) diperlukan suatu metode pembelajaran yang dapatmenstimulus kecerdasannya. Seperti yang kita ketahui kecerdasan masing -masing anak memiliki kecerdasan berbeda-bedatetapi perlu kita sadari bahwa setiap anak nantinya mempunyai kecenderungan untuk memiliki salah satu kecerdasan yang menonjol dibandingkan dengan kecerdasan lainnya.

Sesungguhnya ada beberapa kecerdasan yang terdapat dalam potensi anak berdasarkan jenisnya: diantaranya IQ (intelligence Quotation), SQ (Spiritual Quotation), EQ (Emotional Quotation). Barangkali ada hal yang menjadi tren di negeri kita yakni ESQ (Emotional Spiritual Quotation) yang dikembangkan oleh Ary Ginanjar. Namun dalam penelitian ini penulis lebih merapatkan diri pada aspek kecerdasan yang paling fundamental dalam diri anak usia dini, yaitu kecerdasan majemuk (Multiple Intelligence).

Multiple intelligence atau kecerdasan majemuk pada dasarnya adalah sebuah konsep yang menunjukkan kepada kita bahwa potensi anak-anak kita, khususnya jika dikaitkan dengan kecerdasan,ternyata banyak sekali. Memahami multiple intelligence bukanlah untuk membuat anak-anak kita menjadi hebat. Namun, konsep tersebut, paling tidak dapat membantu kita untuk memahami bahwa anak-anak kita itu menyimpan potensi yang luar biasa.

Suatu kecerdasan juga harus sensitif pada penyandian dalam sistem simbolsimbol arti yang dirancang secara budaya, menangkap dan menyampaikan bentuk informasi yang penting. Bahasa, gambar, matematika adalah tiga sistem simbol yang nyaris mendunia yang penting bagi mempertahankan hidup dan produktivitas manusia. $^{2}$

\section{PEMBAHASAN}

1. Perencanaan Pengembangan Kecerdasan Majemuk melalui Metode Quantum Learning

Sebagaimana dipaparkan dalam teori manajemen, bahwa dalam penyelenggaraan organisasi atau lembaga agar ssuai dengan tujuan diperlukan sebuah perencanaan (planning) yaitu pemilihan atau penetapan tujuan organisasi

\footnotetext{
${ }^{2}$ Howard Gardner, Multiple Inteeligences; Kecerdasan Majemuk, Teori dalam Praktek, (Batam: interaksara), 35-36
}

FALASIFA, Vol. 9 Nomor 2 September 2018 | 37 
Ach Syaikhu

dan penentuan strategi, kebijaksanaan, proyek, program, prosedur, metode, sistem, anggaran dan standar yang dibutuhkan untuk mencapai tujuan.

Begitu juga dengan sebuah penyelenggaraan lembaga pendidikan anak usia dini, harus melalui tahapan perencanaan yang matang. Terlebih dalam sebuah pengembangan. Menurut Harjanto sebagaimana dikutip oleh Luluk Asmawati menjelaskan bahwa isi perencanaan pembelajaran terdiri atas: (1) tujuan sebagai hasil proses pendidikan, (2) program dan layanan pendukung aktifitas pembelajaran, (3) tenaga manusia, yaitu cara-cara mengembangkan prestasi, spesialisasi, perilaku, kompetensi, (4) bangunan fisik sarana dan prasarana, (5) keuangan, (6) struktur organisasi, yaitu cara mengorganisasi dan memanajemen operasi dan pengawasan program dan aktivitas kependidikan yang direncanakan, (7) konteks sosial. ${ }^{3}$

Agar sebuah lembaga dapat berjalan sesuai dengan rencana dan hasil yang luar biasa. Maka, dalam penelitian ini disajikan secara berturut-turut tahapan perencanaan pembelajaran terkait (1) kerangka tujuan pembelajaran, (2) Media dan bahan pembelajaran, (3) metode dan strategi pengembangan, (4) rencana pembelajaran.

\section{Kerangka Tujuan Pembelajaran}

Sebuah kapal pasti memiliki tujuan, teknis, dan waktu kapan dia akan berlayar dan kapan dia akan bersandar di pelabuhan. Tentunya sebuah keputusan yang tidak lepas dari seorang pemegang kendali yakni nahkoda yang didukung penuh oleh kru dan anak buah kapal-nya.

Disamping adanya sekelompok manusia (man) dengan segala kapabilitas, syarat mutlak dari sebuah penyelenggara instituti dan organisasi adalah tujuan. Biasanya tarmaktub dalam sebuah visi- misi dan tujuan lembaga yang nantinya akan di-break down menjadi sebuah program kerja atau rencana kerja sekolah/madrasah dan rencana anggaran kerja sekolah/madrasah yang dirumuskan oleh seluruh stakeholder (pemangku kepentingan) sekolah.

Menurut Muhaimin, hal tersebut dapat digambarkan bahwa setelah diketahui dan ditetapkannya stakeholder utama, maka lembaga sudah mulai jelas dengan hal utama dan yang bukan utama di lembaga tersebut. Kondisi ini akan sangat membantu dalam pemilihan prioritas-prioritas lembaga. Ibarat orang yag akan bepergian jauh, kemampuan organisasi dalam menentukan stakeholder potensialnya sama dengan orang yang pergi jauh tersebut sudah memastikan jalan dan arah yang ditempuh adalah jalan dan arah yang benar.

${ }^{3}$ Luluk Asmawati, Perencanaan Pembelajaran PAUD ..., 2

38 | FALASIFA, Vol. 9 Nomor 2 September 2018 


\section{Media dan Bahan Pembelajaran}

Kegiatan pembelajaran pada dasarnya merupakan proses komunikasi. Agar pesan-pesan pembelajaran yang disampaikan guru dapat diterima dengan baik oleh anak,maka dalam proses komunikasi pembelajran tersebut diperlukan media pembelajaran. Peran media dalam komunikasi pada anak usia dini adalah konsep kekonkretan. Prinsip kekonkretan tersebut memerlukan media sebagai saluran penyampai pesan dari guru kepada anak usia dini. Harapannya dengan adanya pesan melalui media konkret tersebut anak usia dini mengalami perubahanperubahan perilaku berupa kemampuan-kemampuan pengetahuan, sikap, dan keterampilan.

Pengertian media pembelajaran adalah media grafis, tiga dimensi, medi proyeksi, dan pemanfaatan lingkungan sebaai sumber belajar. Nilai media pembelajaran menjadi bagian perkembangan anak secara terintegrasi. Adapaun manfaat media pembelajaran, yaitu: (1) materi pembelajaran akan lebih jelas maknanya sehingga dapat dipahami oleh para siswa, dan siswa menguasai tujuan pembelajaran dengan lebih baik, (2) metode mengajar akan lebih bervariasi, (3) aktivitas siswa dapat lebih terintegrasi melalui pengamatan, melakukan, mendemonstrasikan (seluruh indra berfungsi), (4) materi pembelajaran menjadi lebih menarik dan konkret.

Melalui kegiatan bermain semua indra anak usia dini diharapkan dapat berfungsi optimal sehingga dapat merangsang kemampuan penalarannya. Pada waktu bermain terjadi berbagai eksplorasi, penemuan, penciptaan, perkembangan daya pikir, perkembangan bahasa, perkembangan motorik halus, perkembangan motorik kasar, kebiasaan berbagi, bermain bersama, berimajinasi, dan kreatifitas.

\section{Media dan Bahan Pembelajaran}

Kegiatan pembelajaran pada dasarnya merupakan proses komunikasi. Agar pesan-pesan pembelajaran yang disampaikan guru dapat diterima dengan baik oleh anak,maka dalam proses komunikasi pembelajran tersebut diperlukan media pembelajaran. Peran media dalam komunikasi pada anak usia dini adalah konsep kekonkretan. Prinsip kekonkretan tersebut memerlukan media sebagai saluran penyampai pesan dari guru kepada anak usia dini. Harapannya dengan adanya pesan melalui media konkret tersebut anak usia dini mengalami perubahanperubahan perilaku berupa kemampuan-kemampuan pengetahuan, sikap, dan keterampilan.

Pengertian media pembelajaran adalah media grafis, tiga dimensi, medi proyeksi, dan pemanfaatan lingkungan sebaai sumber belajar. Nilai media pembelajaran menjadi bagian perkembangan anak secara terintegrasi. Adapaun

FaLASIFA, Vol. 9 Nomor 2 September 2018 | 39 
Ach Syaikhu

manfaat media pembelajaran, yaitu: (1) materi pembelajaran akan lebih jelas maknanya sehingga dapat dipahami oleh para siswa, dan siswa menguasai tujuan pembelajaran dengan lebih baik, (2) metode mengajar akan lebih bervariasi, (3) aktivitas siswa dapat lebih terintegrasi melalui pengamatan, melakukan, mendemonstrasikan (seluruh indra berfungsi), (4) materi pembelajaran menjadi lebih menarik dan konkret. Melalui kegiatan bermain semua indra anak usia dini diharapkan dapat berfungsi optimal sehingga dapat merangsang kemampuan penalarannya. Pada waktu bermain terjadi berbagai eksplorasi, penemuan, penciptaan, perkembangan daya pikir, perkembangan bahasa, perkembangan motorik halus, perkembangan motorik kasar, kebiasaan berbagi, bermain bersama, berimajinasi, dan kreatifitas.

\section{Metode dan Strategi Pengembangan}

Sebagaimana dijelaskan diatas terkait perbedaan metode, strategi, model pembelajaran, teknik pembelajaran, dan pendekatan pembelajaran. Bahwa metode pembelajaran dapat diartikan sebagai cara yang digunakan untuk mengimplementasikan rencana yang sudah disusun dalam bentuk kegiatan nyata dan praktis untuk mencapai tujuan pembelajaran. Terdapat beberapa metode pembelajaran yang dapat digunakan untuk mengimplementasikan strategi pembelajaran, diantaranya: (1) ceramah, (2) demonstrasi, (3) diskusi, (4) simulasi, (5) laboratorium, (6) pengalaman lapangan, (7) brainstorming, (8) debat, (9) simposium, dan sebagainya.

Berbeda dengan pandangan Bobbi dePorter tentang metode jika dikaitkan dengan teori pembelajaran quantum, bahwa Quantum Learning adalah seperangkat metode dan falsafah belajar yang terbukti efektif untuk semua umur. Dia mengatakan demikian karena teori quantum learning berkenaan dengan "suggestology" atau "suggesto-pedia". Prinsipnya adalah bahwa sugesti dapat dan pasti memengaruhi hasil situasi belajar, dan setiap detail apapun memeberikan sugesti positif ataupun negatif. ${ }^{4} \mathrm{Hal}$ inilah yang menunjukkan bahwa quantum learning adalah cara mengaplikasikan sebuah teknik terpadu yang terencana. Hal ini sesuai dengan apa yang dijalankan oleh pendidik khususnya dalam lingkungan lembaga pendidikan anak usia dini. Sebagai lembaga yang berorientasi unggul, tentunya tidak boleh lepas dari prinsip peserta didik sebagai tujuan utama (children/student oiented) untuk dikembangkan potensinya. Adapun pemetaan strategi awal sebelum aplikasi pengembangan, yaitu:

\footnotetext{
${ }^{4}$ Bobbi, Quantum Learning, 14
}

40 | FaLASIFA, Vol. 9 Nomor 2 September 2018 
1. Memetakan Kecerdasan Anak

Salah satu jawaban untuk memetakan kecerdasan anak adalah melalui multiple intelligence research (MIR), yaitu instrumen riset yang dapat memberikan deskripsi tentang kecenderungan kecerdasan seseorang. Dari analisis terhadap kecenderungan kecerdasan tersebut, dapat disimpulkan gaya belajar terbaik bagi seseorang. Oleh karena itu, seharusnya setiap guru memiliki data tentang gaya belajar siswanya masing-masing.

MIR adalah riset yang luar biasa untuk membantu guru menemukan gaya belajar siswa. Biasa, MIR dilaksanakan pada saat penerimaan siswa baru. Hasil MIR pada penerimaan siswa menjadi data yang sangat penting bai guru untuk mengetahui kondisi siswa, terutama mengetahui informasi tentang gaya belajarnya. Selanjutnya MIR dapat dilaksanakan pada setiap tahun kenaikan kelas. Data MIR tahun lalu dapat dijadikan masukan untuk pelaksanaan MIR pada tahun depannya.

Hal ini sesuai dengan konsep Howard Gardner bahwa:

"Kecerdasan seseorang itu berkembang, tidak statis. Kecerdasan seseorang lebih banyak berkaitan dengan kebiasaan, yaitu perilaku yang diulangulang". 5

MIR yang dilakukan secara berkala terhdap sesorang dalam hubungannya dengan proses belajar mengajar akan menjadi akselerator baginya untuk menemukan kondisi terbaik

\section{Menemukan Gaya Belajar}

Sebagaimana prinsip pengembangan potensi anak, bahwa banyaknya kegagalan siswa mencerna informsi dari guru disebabkan oleh ketidak sesuaian gaya mengajar guru dengan gaya belajar siswa. Sebaliknya, apabila gaya mengajar guru sesuai dengan gaya belajar siswa, semua pelajaran akan terasa mudah dan menyenangkan. Guru juga senang karena punya siswa yang semuanya cerdas dan berpotensi untuk sukses pada jenis kecerdasan yang dimilikinya.

Jadi, pada dasarnya, gaya mengajar adalah strategi transfer informasi yang diberikan oleh guru kepada siswanya. Sedangkan gaya belajar adalah sebagaimana sebuah informasi dapat diterima dengan baik oleh siswa. Berdasar penelitian yang dilakukan oleh Dr. Howard Gardner, ternyata gaya belajar siswa tercermin dari kecenderungan kecerdasan yang dimiliki oleh siswa tersebut. ${ }^{6}$

Menurut Munif Chatib bahwa pada tahap penempatan kelas unggul berbasis multiple intellegence siswa tidak diklasifikasikan berdasarkan 8

\footnotetext{
${ }^{5}$ Munif Cahatib, Sekolahnya Manusia...., 102

${ }^{6}$ Munif Cahatib, Sekolabnya Manusia....,99
}

FALASIFA, Vol. 9 Nomor 2 September 2018 | 41 
Ach Syaikhu

kecerdasan, namun disesuaikan dengan gaya belajar. ${ }^{7}$ Gaya belajar adalah satusatunya modalitas belajar, yaitu cara informasi masuk ke dalam otak melalui indra yang kita miliki. Pada saat informasi tersebut akan ditangkap oleh indra, maka bagaimana informasi tersebut disampaikan (modalitas) berpengaruh pada kecepatan otak menangkap informasi dan kekuatan otak menyimpan informasi tersebut dalam ingatan atau memori. Terdapat tiga modalitas:

a. Visual: Modalitas ini mengakses citra visual, warna, gambar, catatan, tabel, diagram, grafik, peta pikiran, dan hal-hal lain yang terkait.

b. Auditorial, Modalitas ini mengakses segala jenis bunyi, suara-suara, musik, nada, irama, cerita, dialog, dan pemahaman materi pelajaran dengan menjawab atau mendengarkan cerita lagu, syair, dan hal lain-lain yang terkait.

c. Kinestetik, Modalitas ini mengakses segala jenis gerak, aktifitas tubuh, emosi, koordinasi, dan hal-hal lain yang terkait. ${ }^{8}$

\section{Perencanaan Pembelajaran}

Lesson plan merupakan siklus pertama dari sebuah proses belajar-mengajar yang profesional. ${ }^{9}$ Merencanakan pembelajaran merupakan salah satu kemampuan yang harus dimiliki guru termasuk taman kanak-kanak. Perencanaan pembelajaran yang efektif merupakan acuan dalam melaksanakan pembelajaran yang efektif. Perencanaan pembelajran di TK/PAUD berbeda dengan perencanaan pembelajaran sekolah dasar, atau jenjang pendidikan lainnya, karena di TK menggunakan pendekatan integrated dan tematik. Yang membedakan hanya dalam isi sedangkan komponen-komponen pembelajaran yang ada di dalam perencanaan secara esensi tidak berbeda.

Ada banyak pengertian mengenai perencanaan pembelajaran, namun secara umum dapat disimpulkan bahwa perencanaan pembelajaran adalah rencana yang dibuat oleh guru untuk memproyeksikan kegiatan apa yang akan dilakukan oleh guru dan anak agar tujuan dapat tercapai. Perencanaan pembelajaran mengandung komponen-komponen yang ditata secara sistematis di mana komponen-komponen tersebut saling berhubungan dan saling ketergantungan

${ }^{7}$ Munif Chatib, 2016. Kurikulum 2013 VS Multiple Intellegence untuk Pendidik dan Orang Tua. Dalam Dialog Seminar Nasional diselenggarakan oleh BEM Fakultas Keguruan dan Ilmu Pendidikan Universitas Nahdlatul Ulama Surabaya 10 Desember.

${ }^{8}$ Munif Cahatib, Sekolahnya Manusia...., 136

${ }^{9}$ Munif Chatib, Gurnnya Manusia (Menjadikan Semua Anak Istimewa dan Semua Anaka Juara), 191

42 | FALASIFA, Vol. 9 Nomor 2 September 2018 
satu sama lain. ${ }^{10}$

\section{Pelaksanaan Pengembangan Kecerdasan Majemuk melalui Metode Quantum Learning}

J. K. Rowling adalah seorang penulis yang cerdas dan berhasil. Dia menemukan kondisi akhir terbaiknya pada usia 43 tahun ketika dia berhasil menulis novel Harry Potter pertama kali. Menurut Rowlin, terjadi peurbahan besar terjadi dalam hidupnya saat ia mengalami proses menuangkan ide gilanya ke dalam cerita fiksi Harry Potter. Dengan kata lain, proses penulisan tersebut sebenarnya adalah hakikat kecerdasan yang berjalan. Sedangkan bentuk yang berhasil diwujudkan merupakan kondisi akhir terbaik yang muncul akibat kecerdasan tersebut.

Inilah Multiple Intelleigences yang punya metode discovering ability, artinya proses menemukan kemampuan seseorang. Metode ini meyakini bahwa setiap orang pasti memiliki kecenderungan tersebut harus ditemukan memalui pencarian kecerdasan. Jika yang ditemukan adalah kelemahan dalam satu jenis kecerdasan, kelemahan itu harus dimasukkan ke laci dan kunci rapat-rapat. Multiple Intelligences menyarakan kepada kita untuk mempromosikan kemampuan atau kelebihan seseorang anak dan mengubur ketidakmampuan atau kelemahan anak. Proses menemukan inilah yang menjadi sumber kecerdasan seorang anak.

Tentu, dalam menemukan kecerdasannya, seorang anak harus dibantu oleh lingkungannya, baik orang tua, guru, sekolah, maupun sistem pendidikan yang diimplementasikan di suatu negara. Betapa banyak contoh tokoh-tokoh yang cerdas, terkenal, dan bermanfaat bagi masyarakatnya ternyata banyak memiliki kelemahan.

\section{Evaluasi Pengembangan Kecerdasan Majemuk melalui Metode Quan- tum Learning}

Dalam kaidah manajemen hal yang paling penting adalah sebuah pengukuran hasil kinerja atau yang disebut dengan evaluasi dan penilaian kemudian mengontrol (pengawasan) tindak lanjutnya. Dalam hal ini ada hal yang paling mendasar terkait istilah evaluasi dan penilaian. Asessmen adalah proses mengumpulkan data bukti dan menelaah kebutuhan, keunggulan, kemampuan/abilitas, dan deskripsi pencapaian perkembangan dan belajar anak

${ }^{10}$ Masitoh, dkk. Strategi Pembelajaran TK. Modul 4. Kegiatan Belajar I. Pengertian dan Komponen-komponen Pembelajaran. Materi Pokok PGTK2202/4 SKS/Modul 1 - 12 (2014. Tangerang Selatan: Universitas Terbuka. Edisi 1), 4.3

FALASIFA, Vol. 9 Nomor 2 September 2018 | 43 
Ach Syaikhu

didik dalam kegiatannya di lembaga anak usia dini, antara lain: TPA, KB, posyandu, dan TK. Sedangkan evaluasi adalah: proses mengumpulkan data dasar dan menelaah misalnya tentang efektifitas program belajar dan pembelajaran, seperti misalnya dalam PKB (program kegiatan belajar), kebijakan dan prosedur pelaksanaan PPP (program Pembentukan Perilaku) atau PKD (pengembangan Kemampuan Dasar).

Dibawah ini akan dibahas lebih spesifik pada masalah penilaian dari hasil pelaksnaan pembelajaran berbasis pengembangan multiple intelligences dalam bingkai quantum learning.

\section{Penilaian/Asessmen}

Asessmen merupakan istilah umum yang meiputi semua metoe yang biasa dipakai untuk menjajagi unjuk kerja anak didik secara perorangan atau kelompok kecil.asesmen dapat secara luas merujuk pada banyak sumber bukti dan aspek dari pengetahuan, pengertian, sikap, dan keterampilan anak didik. Atau bisa juga merujuk pada suatu kejadian atau instrumen tertentu, misalnya asesmen portofolio.

Tataran ideal dalam penilaian pendidikan anak usia didni adalah penilaian autentik. Penilaian autentik menganut konsep ability tes, yaitu tes kemampuan, bukan disability tesatau tes ketidak mampuan. Secara filosofis, makna tes ini sangat tepat, sebab tes memang bertujuan mengetahui kemampuan siswa, bukan malah ketidakmampuannya. ${ }^{11}$ Tidak ada anak pulang dalam keadaan stress gara-gara tugas sulit. Namun kesenengan dan semangat belajar di sekolah maupun di rumah.

Teori multiple intelligence menawarkan perombakan yang cukup fundamental dalam penilaian sebagai out put sebuah proses pembelajaran. Teori ini menganjurkan sistem yang tidak bergantung pada tes standar atau tes yang didasarkan pada nilai formal, tetapi lebih banyak didasarkan pada penilaian autentik yang mengacu pada kriteria khusus dengan menggunakan tes yang memiliki titik acuan spesifik dan ipsative (tes yang membandingkan prestasi siswa saat ini dengan prestasi yang lalu. ${ }^{12}$

pendidikan dan pembelajaran bagi anak usia dini, evaluasi dapat dilakukan sebagai berikut:

a. Evalusi Proses

Evaluasi ini dilakukan seketika pada saat proses kegiatan belajar

\footnotetext{
${ }^{11}$ Munif Cahatib, Sekolahnya Manusia...., 157

${ }^{12}$ Munif Cahatib, Sekolahnya Manusia...., 155
}

44 | FALASIFA, Vol. 9 Nomor 2 September 2018 
mengajar berlangsung dengan cara meluruskan atau membetulkan parilaku menyimpang. Hal ini dilakukan oleh pembimmbing dengan cara memberi reward atau demonstrasi secara visual dan konkret.

b. Evaluasi bulanan

Evaluasi ini bertujuan untuk memberi laporan perkembangan atau permasalahan yang ditemukan atau dihadapi oleh pembimbing di sekolah. Evaluasi bulanan ini dilakukan dengan cara mendiskusikan masalah dan perkembangan anak antara guru dan orang tua. Untuk anak autistic dilakukan evaluasi guna mendapatkan pemecahan masalah (solusi), antara lain dilakukan dengan cara mencari penyebab dan luar latar belakang munculnya masalah serta pemecahan masalah. Hal ini dapat dilakukan oleh guru dan orang tua dengan mengadakan diskusi bersama atau case conference.

c. Evaluasi Caturwulan/Semester

Evaluasi ini disebut juga dengan evaluasi program yang dimaksud dengan tolok ukur keberhasilan program secara menyeluruh. Apabila tujuan program pendidikan dan pembelajaran telah tercapai dan dikuasai anak maka kelanjutan program dan kesinambungan program ditingkatkan dengan bertolak dari kemampuan akhir yang dikuasai anak.

Ada banyak model evaluasi yang dapat digunakan untuk mengevaluasi program pembelajaran untuk anak usia dini diantaranya adalah sebagai berikut:

a. Model CIPP (Contact - Input - Process - Product)

Contact evaluasi membantu merencanakan keputusan dan menentukan kebutuhan yang akan dicapai oleh program dan merumuskan tujuan program.

1) Input yang mengatur keputusan, menentukan sumber yang ada, alternatif apa yang diambil, apa rencana dan strategi untuk mencapai kebutuhan

2) Process evaluation mambantu mengimplementasikan keputusan. Sampai sejauh mana rencana telah diterapkan, apa yang harus direvisi. Begitu pertanyaan itu terjawab prosedur dapat dimonitor, dikontrol, dan diperbaiki.

3) Product evaluation merupakan produk untuk menolong keputusan selanjutnya. Apa hasil yang telah dicapai ? dan apa yang dilakukan setelah program berjalan ?

b. Model Brinkerhoff (1983)

Brinkerhoff mengemukakan tiga golongan evaluasi yang disusun berdasarkan penggabungan elemen-elemen, dalam komposisi sebagai berikut:

1) Fixed VS emergent Desain, desain evaluasi yang tetap ditentukan dan direncanakan secara sistematik. Sebelum implementasi dikerjakan. Desai emergent, dibuat untuk beradaptasi dengan pengaruh dan situasi yang

FALASIFA, Vol. 9 Nomor 2 September 2018 | 45 
sedang berlangsung.

2) Formatif VS Sumatif Evaluation. Evaluasi formatif digunakan untuk memperoleh informasi untuk membantu memperbaiki proyek, kurikulum, atau lokakarya. Evaluasi sumatif dibuat untuk kegunaan suatu proyek. Digunakan untuk menilai apakah suatu program akan digunakan atau dihentikan.

3) Experimental and Quasi Experimental desain natural/unobtrusive inquiry. Apakah evaluasi itu akan melibatkan intervensi ke dalam kegiatan program, emncoba memanipulasi kondisi, orang diperlakukan, variabel dipengaruhi, dan sebagainya atau hanya diamati atau keduanya. Natural inquiry, evaluator mengamati, dan berbicara dengan audienceyang relevan. Observasi, studi kasus, laporan tim penyokong merupakan ciri-ciri dari evaluasi ini

\section{c. Goal free evaluation}

Ialah evaluasi program yang dilakukan dengan tuuan yang terlebih dahulu dirumuskan. Ciri-cirinya evaluator sengaja menghindar untuk mengetahui tujuan program. Evaluasi ini berfokus pad ahasil yang sebenarnya, bukan pada hasil yang direncanakan.

d. Asessment Evaluation

Dalam hal ini cara melakukan penilaian pad anak usia dini meliputi: kegiatan pengamatan (observing), pencatatan (recording), dan pendokumentasian (documenting). Kegiatan pengamatan ini dapat dilakukan melalui berbagai teknik diantaranya ialah naratif observation, anecdotal record, running record, time sampling, dan daftar checklist.

Kegiatan pengamatan dapat dilakukan oleh guru ketika ia berinteraksi dengan anak-anak di kelas. Seluruh aspek perkembangan anak dpat dilihat dalam pengamatan. Misalnya, anak-anak yang mengerjakan tugas sesuai dengan perintah guru, anak yang menolong teman dengan meminjamkan pensil atau alat tulis, dan sebagainya. Pengamatan tidak hanya untuk melihat perilaku positif, namun juga perilaku negatif.

\section{PENUTUP}

Manajemen sangatlah penting dan tak bisa terpisahkan dalam pelaksanaan pengelolaan sebuah lembaga, sebab manajemen itu pengaruhnya besar pada eksistensi sebuah lembaga, semakin baik manajemen akan semakin baik pula eksistensi lembaga tersebut. Disisi lain manajemen juga sangatlah penting dalam upaya membantu mengembangkan kecerdasan anak khususnya pada anak usia dini semakin baik manajeman pengembangan kecerdasan anak maka semakin 
besar keberhasilan pendidikan pada anak tersebut. Dari sinilah otimalisasi manajemen perlu menjadi prioritis dalam mengembangkan sebuah lembaga khususnya pengembangan kecerdasan anak didik. Manajemen pengembangan kecerdasan anak pada usia dini ada tiga hal yang harus dilakukan yaitu 1). Perencanaan Pengembangan Kecerdasan anak pada usia dini. Dalam usaha pengembangan kecerdasan anak usia dini sangatlah penting untuk melakukan perencanaan yang matang dan baik. Perencanaan itu natinya dijadikan pedoman dalam mengembangkan kecerdasan anak pada usia dini. 2). Pelaksanaan pengembangan kecerdasan pada anak usia dini dalam hal ini bisa melakukan langkah yaitu:

1. Pengembangan di Lingkungan Lembaga Pendidikan

Pengembangan di lingkungan lembaga pendidikan berupa rasio guru dan siswa yang seimbang, kemampuan guru berimprovisasi, memberikan sugesti (bypno teaching), pendidikan sosial, spiritual, dan moral dengan modal catatan khusus siswa, bisa menjadi dasar untuk mengembangkan potensi anak sehingga tercapai tujuan pendidikan nasional.

2. Pengembangan di Lingkungan Keluarga

Pengembangan di lingkungan keluarga setidaknya ada bimbingan parenting secara periodik, menyeimbangkan kurikulum TK/PAUD dan SD/MI, konseling pihak sekolah orang tua bisa memberikan pemahaman orang tua hakikat pendidikan bagi anak usia dini.

3. Evaluasi pengembangan kecerdasan majemuk melalui metode pembelajaran quantum pada anak usia dini dini

a. Penilaian

Penilaian dalam pengembangan kecerdasan majemuk melalui metode quantum berupa catatan khusus (kepribadian), tes dan pengamatan proses potensi (kecerdasan) anak dalam bentuk klasifikasi, di laporkan dalam bentuk LPPAD agar mampu menumbuh kembangkan potensi secara optimal.

b. Pengawasan

Pengawasan dalam pengembangan potensi pada anak usia dini mendapatkan kontrol dan pengawasan dari pihak terkait seperti dinas pendidikan, yayasan, dan HIMPAUDI sehingga mampu menjadi lembaga yang terjaga mutunya.

\section{DAFTAR PUSTAKA}

Departemen Agama RI. 1984. Al-Qur'an dan Terjemah. Semarang. Howard Gardner, Multiple Inteeligences; Kecerdasan Majemuk, Teori dalam 
Ach Syaikhu

Praktek, (Batam: interaksara).

Munif Chatib, 2016. Kurikulum 2013 VS Multiple Intellegence untuk Pendidik dan Orang Tua. Dalam Dialog Seminar Nasional diselenggarakan oleh BEM Fakultas Keguruan dan Ilmu Pendidikan Universitas Nahdlatul Ulama Surabaya 10 Desember.

Munif Chatib, Gurunya Manusia (Menjadikan Semua Anak Istimewa dan Semua Anaka Juara). Masitoh, dkk. Strategi Pembelajaran TK. Modul 4. Kegiatan Belajar I. Pengertian dan Komponen-komponen Pembelajaran. Materi Pokok PGTK2202/4 SKS/Modul 1 - 12 (2014. Tangerang Selatan: Universitas Terbuka. Edisi 1).

48 | FALASIFA, Vol. 9 Nomor 2 September 2018 